\title{
Characterization of Soybean yellow shoot virus, a New Member of the Family Potyviridae Infecting Soybean Plants in Brazil
}

\author{
Antonia dos Reis Figueira, ${ }^{1,}{ }^{\dagger}$ Priscilla S. Geraldino-Duarte, ${ }^{1}$ Andrés Mauricio Pinzón Nuñez, ${ }^{1}$ Jan van Lent, ${ }^{2}$ \\ Suellen B. F. Galvino-Costa, ${ }^{1}$ M. Farman, ${ }^{3}$ and Michael M. Goodin ${ }^{3}$ \\ ${ }^{1}$ Department of Fitopatologia, Universidade Federal de Lavras, Lavras, Minas Gerais 37200-000, Brazil; ${ }^{2}$ Department of Plant \\ Science, Wageningen University and Research, 6708 PB Wageningen, The Netherlands; and ${ }^{3}$ Department of Plant Pathology, \\ University of Kentucky, Lexington, KY 40546, U.S.A.
}

\begin{abstract}
A new virus species, belonging to the family Potyviridae and capable of infecting most of the soybean cultivars grown in Brazil, was collected in Lavras, Minas Gerais, Brazil, and named Soybean yellow shoot virus (SoyYSV). In this study, the complete 9,052-nucleotide genome of SoyYSV was determined and the structural, biological, and molecular properties of the virus were investigated. The SoyYSV genome encoded a single polyprotein that could be subsequently cleaved, generating 11 proteins. The SoyYSV genome shared $49 \%$ nucleotide and $36 \%$ amino acid sequence identity with Blackberry virus $Y$. However, the $\mathrm{P} 1$ protein of SoyYSV was much smaller and lacked the ALK1 domain

characteristic of the genus Brambyvirus. Electron microscopy revealed flexuous filamentous virus particles, 760 to $780 \mathrm{~nm}$ in length, and cytoplasmic inclusions typical of those found in plant cells infected with Potyviridae species. In addition to soybean, SoyYSV infected species in the Amaranthaceae, Caricaceae, Fabaceae, and Solanaceae families. Among the most common potyviruses present in Brazil, only SoyYSV induced local necrotic lesions in Carica papaya L. SoyYSV was transmissible by Myzus persicae and Aphis gossypii but lacked the HC-Pro domain required for aphid transmission in other potyviruses. No seed transmission in soybean was observed.
\end{abstract}

Soybean [Glycine $\max (\mathrm{L}$.) Merrill] is the main oilseed produced in the world, with an estimated 35.2 million hectares planted in Brazil in 2017 (Companhia Nacional de Abastecimento 2017). According to FAO data, soybean production in 2017 was more than 350 million tons.

Viral diseases, which are among the main limiting factors to soybean production and quality of seed production, can lead to the rejection of entire seed lots destined for export markets. Hill and Whitham (2014) listed 45 virus species that naturally infect the crop and another 30 species that can infect soybeans under experimental conditions. Among these viruses, isolates of Soybean mosaic virus (SMV), Bean pod mottle virus, Soybean vein necrosis virus, Tobacco ringspot virus, Soybean dwarf virus, Peanut mottle virus, Peanut stunt virus, and Alfalfa mosaic virus are considered to cause the greatest economic losses worldwide (Hill and Whitham 2014). More than 10 viruses that infect soybeans have been described in Brazil. However, the majority of losses are attributable to isolates of Tobacco streak virus and Cowpea mild mottle virus (Almeida et al. 2005; Zanardo et al. 2014).

In Brazil, SMV was considered a major limiting factor, with yield losses ranging from 20 to $70 \%$, as all known cultivars were susceptible to this virus (Almeida and Silveira 1983; Almeida et al. 1994; Silva et al. 2003). This led to an intensive search for and incorporation of a resistance factor in all soybean cultivars, since this virus can

${ }^{\dagger}$ Corresponding author: A. R. Figueira; Antonia@dfp.ufla.br

Funding: The authors would like to thank Brazilian Institutions Conselho Nacional de Pesquisa e Desenvolvimento Científico e Tecnológico (CNPq), Coordenação de aperfeiçoamento de Pessoal de Nível Superior (Capes), and Fundação de Amparo a Pesquisa do Estado de Minas Gerais (FAPEMIG) for the resource funds to support the current work.

*The $\boldsymbol{e}$-Xtra logo stands for "electronic extra" and indicates that one supplementary figure is published online.

The author(s) declare no conflict of interest.

Accepted for publication 29 November 2018.

() 2019 The American Phytopathological Society only be controlled by using virus-free seeds and genetic resistance (Hajimorad et al. 2018; Silva et al. 2003). Reports of new species of viruses infecting soybeans have appeared (Coco et al. 2013; Jamil et al. 2017; Lamprecht et al. 2010; Yasmin et al. 2017). In the mid1980 s, a previously undescribed virus disease was identified in soybean plants in Lavras City, Minas Gerais, Brazil. It could elicit novel symptoms, different from those caused by diseases of known etiology. It was initially considered to be a novel strain of SMV or Bean common mosaic virus (BCMV). However, biological and serological tests did not support this hypothesis. According to the symptoms induced in several cultivars, the putative new virus species was named Soybean yellow shoot virus (SoyYSV) and the virus isolate was named Lavras84. It did not react with the antisera produced against SMV and BCMV but presented a serological cross-reaction when tested by double diffusion in agar, with the antisera produced for two Canavalia sp. potyviruses and for Cowpea aphid-borne mosaic virus (CABMV) (Deslandes et al. 1984; Figueira et al. 1991).

The ability of SoyYSV to infect soybean plants with genetic resistance to SMV (Figueira et al. 1991) is of substantial concern because this indicates a great potential to cause crop loss. A more detailed characterization of this virus has become important to identify potential threats to soybean production in Brazil. This study was carried out with the objective of determining the structural, biological, and molecular properties of SoyYSV, including its transmissibility by seeds and by vector. In the course of this study, SoyYSV was found to be a novel member of the family Potyviridae, quite distant from other established genera.

\section{Materials and Methods}

Electron microscopy. Symptomatic sections of soybean leaves were examined by electron microscopy using the leaf-dip technique to identify SoyYSV particles. Small pieces of leaf tissue were placed on a glass slide and a few drops of $0.1 \mathrm{M}$ phosphate buffer, $\mathrm{pH} 7.0$, containing $2 \%(\mathrm{w} / \mathrm{v})$ polyvinyl pyrrolidone and $0.2 \%(\mathrm{w} / \mathrm{v})$ sodium sulfite were added. The leaf tissue was macerated with a glass rod, after which one drop of the extract was placed in Formvar-coated 400- $\mu \mathrm{m}$ mesh copper screens and incubated for $5 \mathrm{~min}$, followed by the addition of $1 \%$ uranyl acetate to provide contrast.

Ultrafine sections were obtained by fixing $3-\mathrm{mm}^{2}$ pieces of infected leaves in SPURR embedding resin/acetone. Fresh leaf pieces 
were placed in Karnovsky buffer (Karnovsky 1965) for 24 h, followed by washing in $0.05 \mathrm{M}$ of sodium cacodylate buffer. The leaf fragments were then placed in osmium tetroxide for $1 \mathrm{~h}$ and washed with distilled water before incubation at $4^{\circ} \mathrm{C}$ for $12 \mathrm{~h}$ in a $0.5 \%$ solution of uranyl acetate. After this period, they were washed again and dehydrated using a gradient series of 30 to $100 \%$ acetone. The fragments were included in SPURR/acetone resin following the $25 \%$, $30 \%, 50 \%$, and $75 \%$ gradient and incubated for at least $8 \mathrm{~h}$ at each dilution. Finally, they were included in $100 \%$ SPURR resin and sectioned on an ultramicrotome. Ultrathin cuts were placed on copper grids coated with Formvar and stained with uranyl acetate. All observations were made using a JEOL JEM1011 transmission electron microscope at Wageningen University and Research.

Virus origin and biological properties. The original inoculum was collected in an experimental soybean field located in Lavras, Minas Gerais, Brazil, in the mid-1980s, multiplied in soybean cultivar Santa Rosa, and stored at $-20^{\circ} \mathrm{C}$ after freeze-drying. Desiccated SoyYSV-infected leaves were used as a source of inoculum of papaya initially. Before propagation in soybean, the inoculum was inoculated in papaya leaves in order to guarantee the purity of the virus isolate through a single local lesion selection. Inoculations for host range study were performed mechanically with SoyYSV inocula prepared by maceration of $5 \mathrm{~g}$ of infected tissues in $10 \mathrm{ml}$ of buffer (10 mM of phosphate buffer, $10 \mathrm{mM}$ of $\mathrm{Na}_{2} \mathrm{SO}_{3}, \mathrm{pH}$ 7).

The hosts screened for susceptibility to SoyYSV were four species of the family Amaranthaceae (Alternanthera tenella, Chenopodium amaranticolor, Chenopodium murale, and Chenopodium quinoa), two Asteraceae (Bidens pilosa and Lactuca sativa), one Caricaceae (Carica papaya), two Cucurbitaceae (Cucurbita maxima and Cucurbita pepo), one Passifloraceae (Passiflora sp.), eight Solanaceae (Capsicum annuum, Datura stramonium, Lycopersicon esculentum, Nicotiana benthamiana, N. glutinosa, N. rustica, N. tabacum, Physalis floridana), and 26 cultivars of five Fabaceae species (Canavalia sp., Phaseolus lunatus, Vigna unguiculata, Phaseolus vulgaris ' $\mathrm{Ca}$ rioca' and 'Preto Campinas,' nine cultivars of G. max susceptible to SMV, and eight cultivars of G. max resistant to SMV). SMVsusceptible cultivars of soybean were Conquista, Confiança, Cristalina, Doko, Liderança, Monsoy, Santa Rosa, Vitória, and UFV5. SMV-resistant cultivars were Favorita, IAC8, Juliana, Numbaíra, Paraná, UFV1, UFV2, and Uirapuru. Four breeding lines of $G$. max also resistant to SMV were also tested: DM399, NS7100 RR, TMG 1176 RR, and TMG 1179 RR.

The experiment was performed by inoculating a total of 60 plants of each species or cultivar, in three replicates using 20 plants each. As a control, the same number of plants was mock inoculated with the buffer only. Plants were grown in 2-kg pots containing pasteurized soil and inoculated 7 days after transplanting. Soybean plants were kept in the greenhouse until the end of the cycle for seed production, and the other species were kept for approximately 40 days for daily visual evaluation of symptoms. Asymptomatic hosts were tested by reverse transcription polymerase chain reaction (RT-PCR) to assess their virus status. The following primers were used to amplify a 525-bp fragment within the viral coat protein (CP) gene: SoySVFCP 5'GGGACGGTGACAAAGCCGC3' (forward) and SoyYSVRCP 5' GGTAATACTGTGGCAGTC3' (reverse).

RT-PCR, Ion Torrent sequencing, and genome analysis. The viral RNA was extracted from viral particles partially purified by the method described in Lane (1992). The pairs of degenerate primers for detection of potyviruses, which were used for cloning fragments of the SoyYSV genome, were described previously by Ha et al.
(2008) and are listed in Table 1. The cDNA syntheses were performed using SoyYSV-extracted RNA, the reverse primers CIRev and N1T (Table 1), and an enzyme mix of M-MLV reverse transcriptase (Promega). The cDNA amplifications by PCR were done with GoTaq Flexi DNA Polymerase (Promega). Both reactions were performed according to the manufacturer's instructions.

For PCR, the reactions were incubated at $95^{\circ} \mathrm{C}$ for $2 \mathrm{~min}$, followed by 30 cycles as follows: $95^{\circ} \mathrm{C}$ for $40 \mathrm{~s}, 42$ to $50^{\circ} \mathrm{C}$ (depending on the primer pair) for $55 \mathrm{~s}$, and $72^{\circ} \mathrm{C}$ for $1 \mathrm{~min}$ for $1 \mathrm{~kb}$. The PCR products were analyzed on $0.7 \%$ agarose gel and purified using the GFX PCR DNA and Gel Band Purification Kit (GE Healthcare, Amersham Biosciences) according to the manufacturer's instructions. The fragments were cloned into pGEM-T Easy Vector (Promega Corp.) and sent for sequencing by GENEWIZ using the universal primers $\mathrm{T} 7$ and SP6.

In parallel, RNA samples extracted from the purified viral particles were prepared for Ion Torrent sequencing at the University of Kentucky Advanced Genetic Technology Center. Poly(A) ${ }^{+}$RNA was purified using total RNA extracted from the isolated SoyYSV particle using the Dynabeads mRNA Purification Kit following the manufacturer's instructions. The cDNA was prepared using the Ion PGM Template OT (One-Touch) 200 Kit (Thermo Fisher Scientific). Sequencing was performed using an Ion PGM Sequencing $200 \mathrm{Kit}$ and Ion 316 chip. Contigs for assembly of the complete sequence of SoyYSV were pooled using high-quality sequences and fragments of the genome obtained initially by RT-PCR with degenerate primers for potyvirus and the Trinity assembler package (Haas et al. 2013). To acquire the genome termini, 3'- and 5'-rapid amplification of cDNA ends (RACE) was performed with the BD-SMART RACE cDNA Amplification Kit according to the manufacturer's instructions (Clontech). For these analyses, cDNA was synthesized by M-MLV reverse transcriptase, and PCRs were conducted with Advantage-II DNA polymerase (Clontech).

The sequence analysis was performed using the National Center for Biotechnology Information (NCBI) Basic Local Alignment Search Tool (BLAST) (NCBI Resource Coordinators 2018). Identification of the coding regions was performed with the open reading frame (ORF) finder, which is available from the NCBI (NCBI Resource Coordinators 2018). For the alignment of the nucleotide and amino acid sequences, the Clustal Omega program (https://www. ebi.ac.uk/Tools $/ \mathrm{msa} /$ clustalo/) was used. Polyprotein cleavage sites were determined by alignment comparisons of sequences with members of the family Potyviridae and a search of data in the literature (Adams et al. 2005a, 2005b). Phylogenetic relationships were studied using the maximum-likelihood algorithm for nucleotides and amino acids using bootstrapping with 3,000 replicates and the MEGA7 program (Kumar et al. 2016) using sequences of different species of the family Potyviridae for comparison.

Seed and vector transmission. Seed transmissibility was investigated using 3,000 seeds: 500 seeds collected from each cultivar presenting light mosaic (Doko, UFV5, and IAC8) and 500 seeds collected from each cultivar showing severe mosaic (Cristalina, Paraná, and Santa Rosa). All of the seeds collected were mixed and the experiment was performed using three replicates of 1,000 seeds each.

The transmissibility of SoyYSV by aphids was investigated using two species common in Brazil: Myzus persicae Sulz. (Hemiptera: Aphididae) and Aphis gossypii Glover (Hemiptera: Aphididae). $M$. persicae aphids were maintained on virus-free Nicandra physaloides plants and A. gossypii aphids were maintained on cotton plants (Gossypium $\mathrm{sp}$.). Initially the aphids were transferred to empty Petri dishes

Table 1. Primers used to amplify the fragments of Soybean yellow shoot virus ${ }^{\mathrm{a}}$

\begin{tabular}{lllc}
\hline Primer & \multicolumn{1}{c}{ Sequence $\left(\mathbf{5}^{\prime} \mathbf{-} \mathbf{3}^{\prime}\right)$} & Conserved domain & Genome position \\
\hline CIFor & GGIVVIGTIGGIWSIGGIAARTCIAC & GxVGSGKST & CI gene \\
CIRev & ACICCRTTYTCDATDATRTTIGTIGC & ATNIIENGV & CI gene \\
NIbFor1 & GGICARCCITCIACIGTIGT & GQPSTVV & NIb gene \\
N1T & GACCACGCGTATCGATGTCGAC(T) $)_{17} \mathrm{~V}$ & & $3^{\prime}-\mathrm{UTR}$ end \\
\hline
\end{tabular}

${ }^{\mathrm{a}} \mathrm{I}=$ inosine, $\mathrm{Y}=\mathrm{C} / \mathrm{T}, \mathrm{R}=\mathrm{G} / \mathrm{A}, \mathrm{W}=\mathrm{A} / \mathrm{T}, \mathrm{V}=\mathrm{A} / \mathrm{C} / \mathrm{G}, \mathrm{S}=\mathrm{C} / \mathrm{G}, \mathrm{D}=\mathrm{A} / \mathrm{G} / \mathrm{T}$, and $\mathrm{UTR}=$ untranslated region. 
and fasted for $60 \mathrm{~min}$. Aphids were given a 30-min acquisition period on SoyYSV-infected soybean Santa Rosa plants. After this period, 10 aphids were transferred to each healthy soybean Santa Rosa plant. The aphids were kept there for $24 \mathrm{~h}$ before they were eliminated with methomyl (Lanate BR liquid formulation, $215 \mathrm{~g}$ per liter). The plants remained in the greenhouse until the appearance and evaluation of symptoms, from 15 to 30 days. For each aphid species tested, 10 plants with three replicates were used.

Table 2. Reaction of different plant species mechanically inoculated with Soybean yellow shoot virus

\begin{tabular}{|c|c|c|}
\hline Family & Plant species & Symptoms $^{\mathbf{a}}$ \\
\hline \multirow[t]{4}{*}{ Amaranthaceae } & Alternanthera tenella & SCL \\
\hline & $\begin{array}{l}\text { Chenopodium } \\
\text { amaranticolor }\end{array}$ & NLL \\
\hline & Chenopodium murale & WS \\
\hline & Chenopodium quinoa & NLL \\
\hline \multirow[t]{2}{*}{ Asteraceae } & Bidens pilosa & WS \\
\hline & Lactuca sativa & WS \\
\hline Caricaceae & Carica papaya & NLL \\
\hline \multirow[t]{2}{*}{ Cucurbitaceae } & Cucurbita maxima & WS \\
\hline & Cucurbita pepo & WS \\
\hline Passifloraceae & Passiflora sp. & WS \\
\hline \multirow[t]{8}{*}{ Solanaceae } & Capsicum аппиит & WS \\
\hline & Datura stramonium & WS \\
\hline & Lycopersicon esculentum & WS \\
\hline & Nicotiana benthamiana & $\mathrm{CM}, \mathrm{VC}$ \\
\hline & N. glutinosa & WS \\
\hline & N. rustica & WS \\
\hline & N. tabacum & WS \\
\hline & Physalis floridana & WS \\
\hline \multirow[t]{26}{*}{ Fabaceae } & Glycine max 'Conquista'b,c & CLL, CM, YS, C, FP \\
\hline & G. max 'Confiança'c & CLL, NLL, LD, VN, FP \\
\hline & G. max 'Cristalina'd & GM, C, B, S, FP \\
\hline & G. $\max$ 'Doko'c & FM \\
\hline & G. $\max$ 'Favorita'd & M, LD, NLL, S, FP \\
\hline & G. $\max$ 'IAC8'd & MM, B \\
\hline & G. $\max$ 'Juliana'c & $\begin{array}{l}\text { CM, LD, NLL, CLL, B, S, } \\
\text { FP }\end{array}$ \\
\hline & G. max 'Liderança'c & CLL, CM, LD, VN, FP \\
\hline & G. $\max$ 'Monsoy'c & CLL, CM, LD, C, FP \\
\hline & G. max 'Numbaíra'd & CLL, C, NM, YS, NSP \\
\hline & G. max 'Paraná'd & $\mathrm{CM}, \mathrm{S}, \mathrm{VN}, \mathrm{YS}$ \\
\hline & G. max 'Santa Rosa'c & $\mathrm{CM}, \mathrm{C}, \mathrm{LD}, \mathrm{S}, \mathrm{YS}, \mathrm{FP}$ \\
\hline & G. $\max$ 'Vitória'c & $\mathrm{M}, \mathrm{C}, \mathrm{YS}, \mathrm{FP}$ \\
\hline & 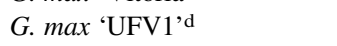 & GM, B \\
\hline & G. $\max$ 'UFV2'd & MM \\
\hline & G. $\max { }^{\prime} \mathrm{UFV}^{\prime}{ }^{\prime} \mathrm{c}$ & $\mathrm{CM}, \mathrm{LD}, \mathrm{B}, \mathrm{FP}$ \\
\hline & G. $\max$ 'Uirapuru'd & SCL, M, YS, FP \\
\hline & G. $\max$ Ln. DM399b,d & YS, ML, LD, C, VN, FP \\
\hline & G. $\max$ Ln. NS7100 RR ${ }^{\mathrm{b}, \mathrm{d}}$ & CM, NLL, NS, FP \\
\hline & G. $\max$ Ln. TMG $1176 \mathrm{RR}^{\mathrm{b}, \mathrm{d}}$ & $\mathrm{CM}, \mathrm{C}, \mathrm{LD}, \mathrm{S}, \mathrm{FP}$ \\
\hline & G. $\max$ Ln. TMG $1179 \mathrm{RR}^{\mathrm{b}, \mathrm{d}}$ & $\mathrm{CM}, \mathrm{C}, \mathrm{LD}, \mathrm{S}, \mathrm{FP}$ \\
\hline & Canavalia sp. & $\mathrm{CM}, \mathrm{C}, \mathrm{LD}$ \\
\hline & Phaseolus lunatus & NLL, TN, PD \\
\hline & $\begin{array}{l}\text { Phaseolus vulgaris } \\
\text { 'Carioca' }\end{array}$ & $\mathrm{VN}, \mathrm{C}, \mathrm{PD}$ \\
\hline & $\begin{array}{l}\text { Phaseolus vulgaris 'Preto } \\
\text { Campinas' }\end{array}$ & VN, CM, PD \\
\hline & Vigna unguiculata & $\mathrm{CM}, \mathrm{S}$ \\
\hline
\end{tabular}

a Symptoms: $\mathrm{SCL}=$ systemic chlorotic lesion, $\mathrm{NLL}=$ necrotic local lesion, $\mathrm{WS}=$ without symptoms, $\mathrm{CM}=$ common mosaic, $\mathrm{VC}=$ vein clearing, $\mathrm{CLL}=$ chlorotic local lesion, $\mathrm{YS}=$ yellow shoot, $\mathrm{C}=$ crinkling, $\mathrm{FP}=$ fewer pods, $\mathrm{LD}=$ leaf distortion, $\mathrm{VN}=$ veinal necrosis, $\mathrm{GM}=$ golden mosaic, $\mathrm{B}=$ blistering, $\mathrm{S}=$ stunting, $\mathrm{FM}=$ faint mosaic, $\mathrm{M}=$ mosaic, $\mathrm{MM}=$ mild mosaic, $\mathrm{NM}=$ necrotic mosaic, $\mathrm{NSP}=$ no seed production, $\mathrm{TN}=$ top necrosis, and $\mathrm{PD}=$ premature death

${ }^{\mathrm{b}} \mathrm{Ln}=$ genetic lineage.

c Soybean mosaic virus (SMV)-susceptible cultivar.

d SMV-resistant cultivar.

\section{Results}

Electron microscopy. Ultramicroscopic analysis of SoyYSVinfected leaf tissues showed flexuous particles measuring approximately 760 to $780 \mathrm{~nm}$ in length. Cytoplasmic cylindrical inclusions appeared as pinwheels, scrolls, and laminated aggregates, which are typical characteristics of viruses of the family Potyviridae (Supplementary Fig. S1).

Host range. All of the plants mock inoculated with buffer did not show any symptoms. The species of plants belonging to the families Asteraceae, Cucurbitaceae, and Passifloraceae also showed no symptoms when inoculated with SoyYSV (Table 2) and showed negative results when tested by RT-PCR. All susceptible plants showed an infection rate of 100\%, confirmed by RT-PCR. Carica papaya plants (Caricaceae family) reacted with necrotic local lesions and showed no systemic infection (Fig. 1A). N. benthamiana plants, which were the only susceptible plants among the eight inoculated solanaceous species, showed vein chlorosis, mosaic, and bronzing in inoculated and noninoculated leaves. The other solanaceous species were asymptomatic and tested negative by RT-PCR. SoyYSV is the only known potyvirus able to induce necrotic local lesions in Carica papaya. Therefore, these plants are highly important as diagnostic species. Moreover, plants of Chenopodium amaranticolor and Chenopodium quinoa reacted with necrotic local lesions only in the inoculated leaves and may also be used as a diagnostic species for SoyYSV (Fig. 1, B and C). RT-PCR of noninoculated asymptomatic leaves was negative. A. tenella, a common weed in soybean crops (Dourado-Neto et al. 2013), presented chlorotic local lesions in inoculated leaves, which became systemic, appearing in all of the older leaves during the course of infection.

All species of Fabaceae, which were mechanically inoculated, were infected (Table 2), but cultivar Doko showed only a faint, light-green mosaic, indicating tolerance to SoyYSV. Approximately 10 to 15 days after mechanical inoculation, the soybean plants presented symptoms ranging from mild mosaic (IAC-8 and UFV2) to severe necrosis (Numbaíra) (Fig. 1, D to G) and generated a strong 525-bp PCR band. Some even died when inoculated early. The cultivars Conquista, Liderança, Monsoy, Numbaíra, and Uirapuru showed chlorotic local lesions only in the inoculated leaves, followed by systemic mosaic (Table 2). The cultivars Cristalina and UFV1 showed golden mosaic. Leaf wrinkling and necrosis located in the veins, systemic necrosis, blistering, and stunting were frequently observed. Excluding the cultivar Doko, all of the seeds produced by soybean cultivars infected with SoyYSV were smaller and presented coat mottling ranging from dark streaks to large spots attributable to hilum bleeding, in which the hilum color spreads out into the seed coat.

The bean cultivars Carioca and Preto Campinas were highly sensitive, as they presented necrotic lesions in inoculated primary leaves. This was followed by systemic infection and nanism. Phaseolus lunatus showed necrosis in the inoculated leaves, followed by top necrosis and death about 30 days after inoculation. All of the symptomless inoculated plants were found negative based on RT-PCR assays.

RT-PCR, SoyYSV genome cloning, and sequencing. The use of degenerate primers targeting conserved regions in the $\mathrm{CI}$ and $\mathrm{NIb} / \mathrm{CP}$ cistrons (Table 1) produced two PCR bands: $1.6 \mathrm{~kb}$ containing part of the NIb and $\mathrm{CP}$ cistrons at the $3^{\prime}$ terminus and $682 \mathrm{bp}$ containing part of the CI cistron (Geraldino-Duarte et al. 2012). These PCR products were cloned, sequenced, and found to represent a distantly related species of a member of the family Potyviridae. The $3^{\prime}$ region, spanning $\mathrm{NIb}$ and $\mathrm{CP}$, showed the highest identity with potyviruses compared with virus genomes from GenBank, ranging from 55 to $59 \%$ for nucleotide sequences and from 29 to $32 \%$ for amino acid sequences, respectively. The CI-spanning fragment also showed 51 to $63 \%$ nucleotide identity and 44 to $47 \%$ amino acid identity with potyviruses.

To characterize the whole genome of SoyYSV, Ion Torrent sequencing technology was employed, supplemented with RACE methodology to acquire the $5^{\prime}$ - and $3^{\prime}$-terminal sequences. Assembly 


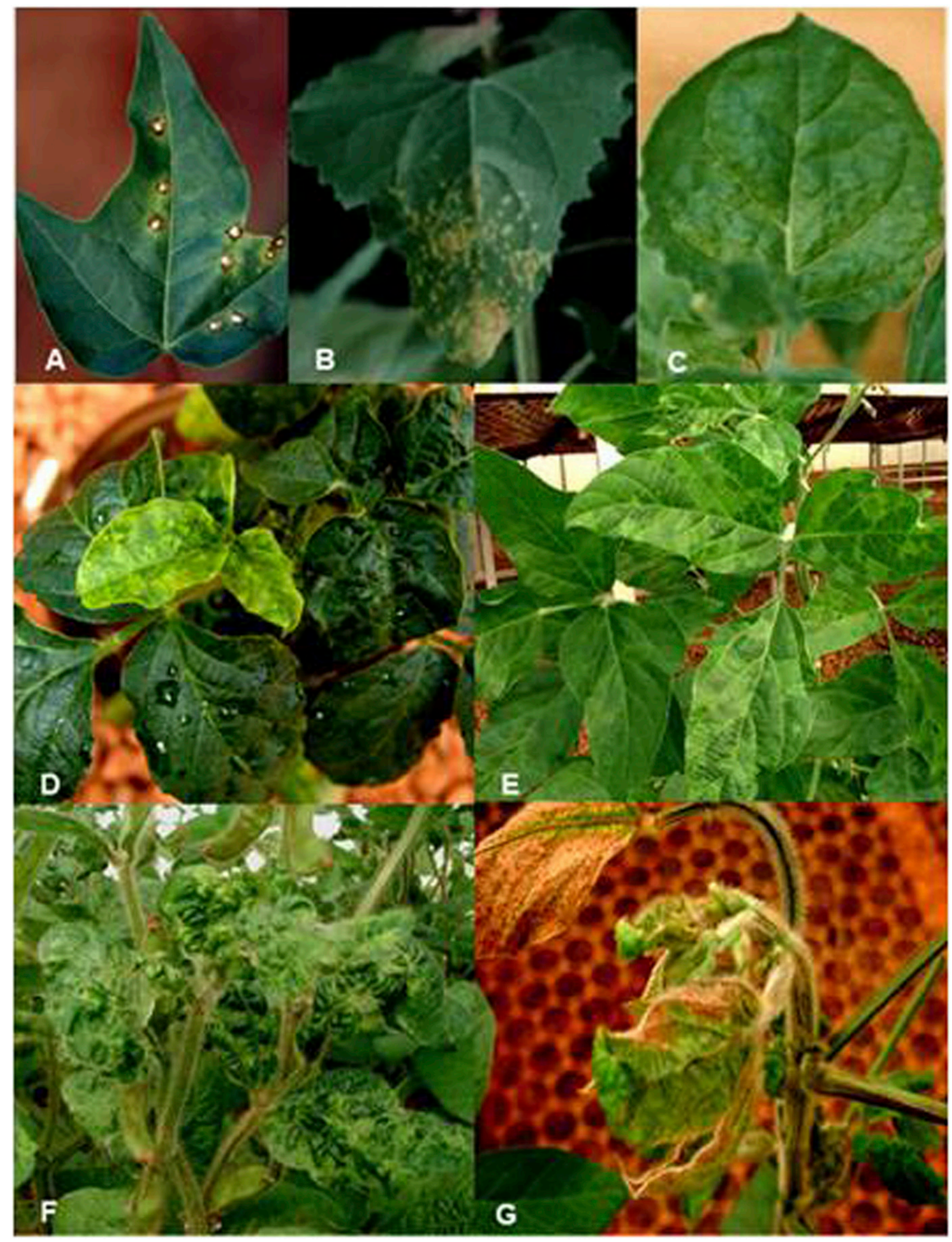

Fig. 1. Symptoms shown by susceptible plants infected with soybean yellow shoot virus. A, Carica papaya. B, Chenopodium amaranticolor. C, Nicotiana benthamiana. D, Typical yellow shoot in soybean cultivar Paraná. E, Mild mosaic in cultivar UFV-2. F, Severe mosaic in cultivar Juliana. G, Necrotic mosaic in cultivar Numbaíra. 
of the RNA sequencing data into contigs, using the Trinity program (Haas et al. 2013), was processed using 25 nucleotides (nt) as the minimal overlapping length (k-mer), which yielded $379.98 \mathrm{Mbp}$ of total reads. Among them, 294.07 Mbp (1,912,731 reads) were considered of high quality (Q20), with lengths ranging from 65 to $382 \mathrm{bp}$. Searches using BLASTN and BLASTX detected one cluster having sequence identity to known members of the family Potyviridae. After assembly, the complete genome of SoyYSV was found to consist of 9,052 nt, excluding the poly(A)tail at the $3^{\prime}$ end.

Sequence analysis of the SoyYSV genome. The nucleic acid sequence of SoyYSV showed the typical genome organization of a potyvirus species and was submitted to GenBank under accession number MH890547. The single ORF initiates with an AUG at position 173 and terminates at an UAA at position 8,890. The first $172 \mathrm{nt}$ located at the $5^{\prime}$ region of the virus genome correspond to the $5^{\prime}$ untranslated region (UTR), and the $3^{\prime}$-UTR is positioned between nucleotides 8,891 and 9,052. Both regions showed great variation (6 to $21 \%$ identity) compared with other potyviruses. However, the block UCAACUC at positions 26 to 32 and the block UCAAGCU at positions 45 to 51, which have been identified in most members of the family Potyviridae, were present in the 5'-UTR of SoyYSV.

The SoyYSV polyprotein is 2,905 amino acids (aa) long and contains predicted protease cleavage sites for potyviruses to generate peptides in the following order: P1, HC-Pro, P3, 6K1, CI, VPg, 6K2, NIa Pro, NIb, and CP (Fig. 2; Table 3) (Wylie et al. 2017). Likewise, when the polyprotein sequence was compared using NCBI's Conserved Domain Database (Marchler-Bauer et al. 2017), the conserved domains characteristic of potyviruses were also identified.

At the N-terminal region of the SoyYSV polyprotein, the amino acids that are characteristic of the $\mathrm{P} 1$ protein were identified as the conserved GDSG motif at position 244 to 247 aa responsible for its proteolytic activity (Verchot et al. 1991). Conserved amino acid sequences for a cysteine-like protease have also been identified in the SoyYSV sequence corresponding to HC-Pro, which were initially described as being associated with aphid transmission and subsequent suppression of posttranscriptional gene silencing (Plisson et al. 2003). However, motifs such as KMTC and PTK, described as important in virus transmission by aphids (Revers and García 2015), were not identified in the sequence. Only the FRNK motif, associated with the expression of symptoms, was detected at positions 408 to 411 , and the GYCY motif, which is characteristic of cysteine-type proteases, was found at positions 490 to 493 (Stenger et al. 2006).

The conserved $\mathrm{P} 3$ protein domains were found in the sequence between amino acids 614 and 959. The GA6 sequence within the P3 protein (Chung et al. 2008) that is characteristic of the small ORF PIPO can also be identified from nucleotides 2,819 to 2,995. In CI protein, the conserved motif NTP-binding GxxGxGKS starting at amino acid 1,021, and the helicase-based motif DEXDc, starting at amino acid 1,349 (Kadaré and Haenni 1997), were identified and confirmed by BLASTP.

Downstream is the cleavage site that gives rise to the VPg protein, which later covalently binds to the $5^{\prime}$ terminus of genomic RNA and plays a key role in the initiation and synthesis of viral RNA (Eskelin et al. 2011; Siaw et al. 1985). The NIa protein has a conserved domain of $\mathrm{C} 4$ family peptidases, which are present in potyviruses. It consists of a long protein associated with the formation of nuclear crystalline inclusions (Revers and García 2015). The other protein, called NIb, which is associated with nuclear inclusions and has the conserved RNA-dependent RNA polymerase domains (Hong and Hunt 1996), was found between amino acids 2,265 to 2,538 of SoyYSV. In addition to NIb motif, conserved sequences characteristic of potyvirus $\mathrm{CP}$ called core region were found between the amino acids 2,661 and 290 (Voloudakis et al. 2004).

Table 3 shows the size and location of the proteins in the SoyYSV genome, based on their cleavage sites, and the protein isoelectric points. Table 4 shows the highest SoyYSV nucleotide and amino acid identities with members of the family Potyviridae, available in GenBank. Generally, the highest identities ranged from 42 to $56 \%$ for nucleotides and 21 to $54 \%$ for amino acids. All proteins had the highest identity with either potyviruses or the brambyvirus Blackberry virus $Y$ (BVY) (Table 4). The only exception was the $6 \mathrm{~K} 2$ protein, which showed higher amino acid identity with the rymovirus Agropyron mosaic virus (AgMV) (29\%), despite having the highest nucleotide identity with Zucchini yellow mosaic virus (ZYMV) (48\%).

Some proteins, such as $\mathrm{P} 3,6 \mathrm{~K} 1$, and NIa, showed higher nucleotide identity with brambyvirus and higher amino acid identity with potyvirus and vice versa. The proteins $\mathrm{P} 1, \mathrm{CI}, \mathrm{VPg}, \mathrm{NIb}$, and $\mathrm{CP}$, as well as the complete genome of SoyYSV, showed higher nucleotide and amino acid identity with BVY of the genus Brambyvirus, ranging from 46 to $56 \%$ for nucleotides and from 21 to $54 \%$ for amino acids. The HC-Pro, P3, 6K1, 6K2, and PIPO proteins showed higher nucleotide identity with the following Potyvirus species: ZYMV, BMV, Potato virus Y (PVY), Bean common mosaic necrosis virus (BCMNV), and Beet mosaic virus, ranging from 40 to $50 \%$. However, only HC-Pro and PIPO showed higher amino acid identity with potyviruses ZYMV and BCMNV. The $\mathrm{P} 3$ and $6 \mathrm{~K} 1$ proteins showed higher amino acid identity with the brambyvirus BVY, whereas $6 \mathrm{~K} 2$ showed higher amino acid identity with the rymovirus AgMV (29\%). NIa, despite presenting 46\% nucleotide identity with brambyvirus, showed higher amino acid identity (29\%) with the potyvirus CABMV.

Table 3. Description of the protein size, isoelectric point (pI), and localization of cleavage sites within Soybean yellow shoot virus polyprotein

\begin{tabular}{|c|c|c|c|c|}
\hline \multirow[b]{2}{*}{ Protein $^{a}$} & \multirow[b]{2}{*}{ Size (kDa) } & \multirow[b]{2}{*}{ pI } & \multicolumn{2}{|c|}{ Polyprotein cleavage sites $5^{\prime} \rightarrow 3^{\prime}$} \\
\hline & & & Motif & Amino acid position \\
\hline $\mathrm{P} 1$ & 34 & 9.33 & MLFY/G & $1-300$ \\
\hline HC-Pro & 33 & 6.62 & YKVG/G & $301-605$ \\
\hline P3 & 39 & 9.24 & NLQS/K & $606-950$ \\
\hline $6 \mathrm{~K} 1$ & 7 & 4.81 & ESSEMQ/A & $951-1,014$ \\
\hline CI & 69 & 8.06 & FSMLKD/N & $1,015-1,631$ \\
\hline $6 \mathrm{~K} 2$ & 7 & 5.04 & ELTTLN/M & $1,632-1,693$ \\
\hline VPg & 20 & 7.8 & PILNPE/S & $1,694-1,872$ \\
\hline $\mathrm{Nia}$ & 17 & 9.85 & VIAQ/S & $1,873-2,030$ \\
\hline $\mathrm{Nib}$ & 69 & 5.45 & VLTPQ/N & $2,031-2,634$ \\
\hline $\mathrm{CP}$ & 30 & 6.07 & - & $2,635-2,905$ \\
\hline PIPO & 7 & 6.14 & - & 883-941 \\
\hline Full ORF & 329 & & - & $1-2,905$ \\
\hline
\end{tabular}

${ }^{\mathrm{a}} \mathrm{CP}=$ coat protein and $\mathrm{ORF}=$ open reading frame.

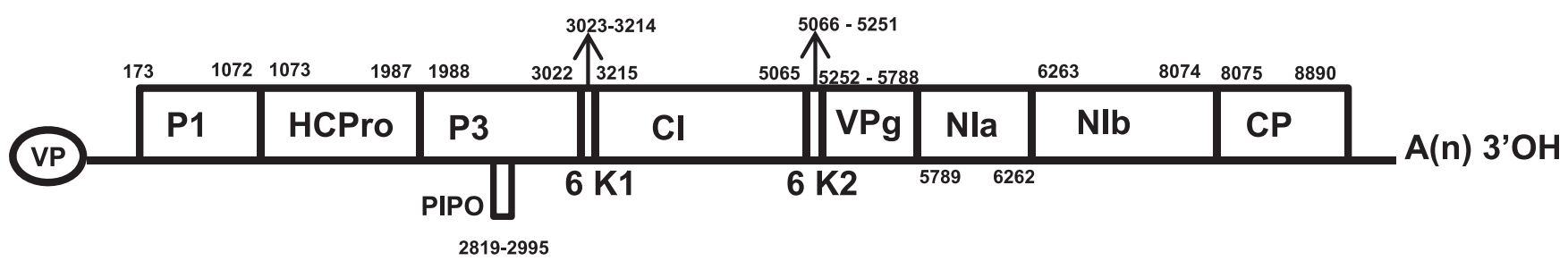

Fig. 2. The predicted genomic organization of Soybean yellow shoot virus (isolate Lavras84). The positions in the nucleotide sequence of predicted cleavage sites are indicated by arrows. 
In general, the amino acid identities were lower than the nucleotide identities, which indicated that the nucleotide substitutions were nonsynonymous (Nei and Gojobori 1986). The highest amino acid identity occurred between NIb (54\%) and CP (44\%) of SoyYSV and respective brambyvirus proteins, whereas the other identities were much lower, ranging from 25 to $40 \%$.

The phylogenetic trees based on the nucleotide sequences of the complete ORF (Fig. 3A) showed, as expected, the separation of the species in clades according to the genus for the other species used in the analysis. SoyYSV remained in the same clade as BVY, the only representative of the genus Brambyvirus.

Seed and vector transmissibility. None of the seeds planted generated diseased plants, suggesting that either SoyYSV is not transmitted by the seeds of the tested cultivars or that it is transmitted at a rate lower than 1/1,000 seeds. Both tested aphid species transmitted SoyYSV. However, M. persicae was the most efficient, transmitting the virus to $70 \%$ of the aphid-inoculated plants, whereas A. gossypii transmitted to only $40 \%$ of inoculated plants. Symptoms appeared about 2 weeks after inoculation with the viruliferous vectors. The control plants that received the virus-free aphids showed no symptoms during the course of the experiments, up to 30 days after vector inoculation. The symptoms observed in the aphid-inoculated plants were less severe than those seen in the mechanically inoculated plants.

\section{Discussion}

This study suggests that SoyYSV, a virus first detected on soybean in Lavras, Minas Gerais, Brazil, is a novel and very peculiar species. Electron microscopy indicated that SoyYSV induced the formation of cylindrical cytoplasmic inclusions characteristic of members of the Potyviridae (Edwardson 1966; Sorel et al. 2014; Wylie et al. 2017). According to the classification proposed by Edwardson and Christie (1978) and Edwardson et al. (1984), the inclusions observed in SoyYSV-infected tissues merit its assignment to the Type III subgroup, given that this virus induces pinwheels, scrolls, and laminated aggregates. Although the types of subcellular inclusions induced by potyviruses were once used to classify new viral species (Edwardson and Christie 1978; Edwardson et al. 1984), it was later concluded that they lacked sufficient resolution for differentiating species strains of the same virus species. Therefore, we expanded the characterization of SoyYSV to include biological and molecular characteristics, such as host range, vector, pathogenicity, and genome sequences (Adams et al. 2005a, b).
The symptoms observed when SoyYSV was mechanically inoculated denoted that it has high potential to cause severe damage to soybean crops in Brazil. Importantly, SoyYSV can infect soybean species resistant to SMV and thus represents a potential threat to soybean production. Plants resistant to SMV were susceptible to SoyYSV and vice versa (Table 2), indicating that the genetic resistance might be related to different genes. This means that obtaining SoyYSV-resistant plants would be an additional task for soybean breeding programs. Moreover, SoyYSV has a broad host range, which indicates that it can easily survive in fields during the year as it is disseminated to soybean crops by aphids. A. tenella, which is an important weed in soybean crops (Dourado-Neto et al. 2013), is susceptible to SoyYSV and could act as an alternative host.

An important difference between the genome of SoySV and the genome of potyviruses was the lack of the HC-Pro motifs KMTC and PTK, which are reportedly involved in aphid transmission of viruses (Revers and García 2015). Even with the absence of those domains, SoyYSV was transmitted by the aphids $M$. persicae and A. gossypii.

Typically the specificity between virus and vector is very narrow and is mediated by specific interactions between the vector and virusspecific proteins, such as $\mathrm{CP}$ and HC-Pro (Flasinski and Cassidy 1998; Goytia et al. 2006). A number of functionally equivalent domains capable of playing similar roles in virus acquisition by aphids have been reported (Dombrovsky et al. 2005; Flasinski and Cassidy 1998). Examples of such domains include, but are not limited to, the presence of a histidine in the C-terminal region of the $\mathrm{CP}$ and an arginine close to the cleavage site at the $\mathrm{C}$ terminus of SMV HC-Pro (Seo et al. 2010) and a lysine at position 68 of the PVY CP, which appear to increase the viral transmission efficiency (Moury and Simon 2011). Aphids are most often associated with the transmission of species of the Potyvirus and Macluravirus genera. To date, no vector has been identified for transmission of Brambyvirus species (Whitfield et al. 2015). However, it is proposed to be transmitted by airborne vectors.

A comparison of 187 complete sequences from different genera of the family Potyviridae found that most species showed 50 to $55 \%$ nucleotide identity with other members of the same genus, but there were subgroups with higher identities (Adams et al. 2005a). Therefore, the authors suggested identities of up to $76 \%$ for nucleotides and $82 \%$ for amino acids as demarcation criterion for species. Based on a nucleotide identity of $49 \%$, SoyYSV is most closely related to BYV. According to Adams et al. (2005a), this could not place it within the genus Brambyvirus. In addition, the main characteristic

Table 4. Highest nucleotide and amino acid identity between Soybean yellow shoot virus and species of the family Potyviridae

\begin{tabular}{|c|c|c|c|c|c|c|}
\hline \multirow[b]{2}{*}{ Protein $^{\mathbf{a}}$} & \multicolumn{3}{|c|}{ Highest nucleotide identity presented by each SoyYSV protein } & \multicolumn{3}{|c|}{ Highest amino acid identity presented by each SoyYSV protein } \\
\hline & Virus species & Accession no. and genus & $\%$ & Virus species & Accession no. and genus & $\%$ \\
\hline $\mathrm{P} 1$ & Blackberry virus $Y$ & NC_008558, Brambyvirus & 48 & Blackberry virus $Y$ & NC_008558, Brambyvirus & 25 \\
\hline HC-Pro & $\begin{array}{l}\text { Zucchini yellow mosaic } \\
\text { virus }\end{array}$ & KT598222, Potyvirus & 43 & $\begin{array}{l}\text { Zucchini yellow mosaic virus, } \\
\text { Bean common mosaic } \\
\text { necrosis virus }\end{array}$ & $\begin{array}{l}\text { KT598222, NC004047, } \\
\text { Potyvirus }\end{array}$ & 29 \\
\hline P3 & Soybean mosaic virus & NC_002634, Potyvirus & 40 & Blackberry virus $Y$ & NC_008558, Brambyvirus & 21 \\
\hline $6 \mathrm{~K} 1$ & Potato virus $Y$ & NC_001616, Potyvirus & 50 & Blackberry virus $Y$ & NC_008558, Brambyvirus & 35 \\
\hline CI & Blackberry virus $Y$ & NC_008558, Brambyvirus & 51 & Blackberry virus $Y$ & NC_008558, Brambyvirus & 40 \\
\hline $6 \mathrm{~K} 2$ & $\begin{array}{l}\text { Zucchini yellow } \\
\text { mosaic virus }\end{array}$ & KT598222, Potyvirus & 48 & Agropyron mosaic virus & NC_005903, Rymovirus & 29 \\
\hline VPg & Blackberry virus $Y$ & NC_008558, Brambyvirus & 53 & Blackberry virus $Y$ & NC_008558, Brambyvirus & 39 \\
\hline $\mathrm{Nia}$ & Blackberry virus $Y$ & NC_008558, Brambyvirus & 46 & $\begin{array}{l}\text { Cowpea aphid-borne mosaic } \\
\text { virus }\end{array}$ & NC_003797, Ipomovirus & 29 \\
\hline $\mathrm{Nib}$ & Blackberry virus $Y$ & NC_008558, Brambyvirus & 56 & Blackberry virus $Y$ & NC_008558, Brambyvirus & 54 \\
\hline $\mathrm{CP}$ & Blackberry virus $Y$ & NC_008558, Brambyvirus & 53 & Blackberry virus $Y$ & NC_008558, Brambyvirus & 44 \\
\hline PIPO & Beet mosaic virus & NC005304, Potyvirus & 42 & $\begin{array}{l}\text { Bean common mosaic necrosis } \\
\text { virus Soybean mosaic virus }\end{array}$ & $\begin{array}{l}\text { NC004047, NC_002634, } \\
\text { Potyvirus }\end{array}$ & 25 \\
\hline Full ORF & Blackberry virus $Y$ & NC_00858, Brambyvirus & 49 & Blackberry virus $Y$ & NC_003483, Bymovirus & 36 \\
\hline
\end{tabular}

${ }^{\mathrm{a}} \mathrm{CP}=$ coat protein and $\mathrm{ORF}=$ open reading frame. 
of the Brambyvirus species is to encode a P1 bigger than any other member of the family Potyviridae, showing an ALK1 domain (Wylie et al. 2017). The $P 1$ protein of brambyviruses is more than 740 aa long, whereas that of SoyYSV is less than half that size (at 300 aa). Furthermore, the ALK1 domain is absent in the SoyYSV P1 protein.

On the other hand, the highest nucleotide and amino acid identity of SoySV CP with potyviruses was observed with BCMNV (45\% and $33 \%$, respectively), and the nucleotide identity ranged from 40 to $42 \%$ and the amino acid identity ranged between 29 and $30 \%$ for the entire genome (data not shown). Therefore, considering the morphology, cytological symptoms, and aphid transmission, SoyYSV could be allocated to the Potyviridae family, but the identities of nucleotide and amino acids between SoyYSV and other potyvirids did not allow us to place it in any of the recognized genera.

Newly emerging Potyviridae species and genera have frequently been reported. Within the current demarcation criteria, the International Committee on Taxonomy of Viruses (ICTV) approved three new genera in the family Potyviridae, distinct from any existing genus: Bevemovirus, Roymovirus, and Poacevirus (Mollov et al. 2013; Seo et al. 2017b; Tatineni et al. 2009; Wylie et al. 2017; Xu et al. 2010). Another virus, Spartina mottle virus, was recognized by the ICTV as a new species of Potyviridae; however, it has not yet been formally placed in any genus (Götz et al. 2002; Wylie et al. 2017). Longan witches' broom-associated virus also seems to be a new species that has typical characteristics of the family Potyviridae, but it exhibits low identity with all genera (Seo et al. 2017a).
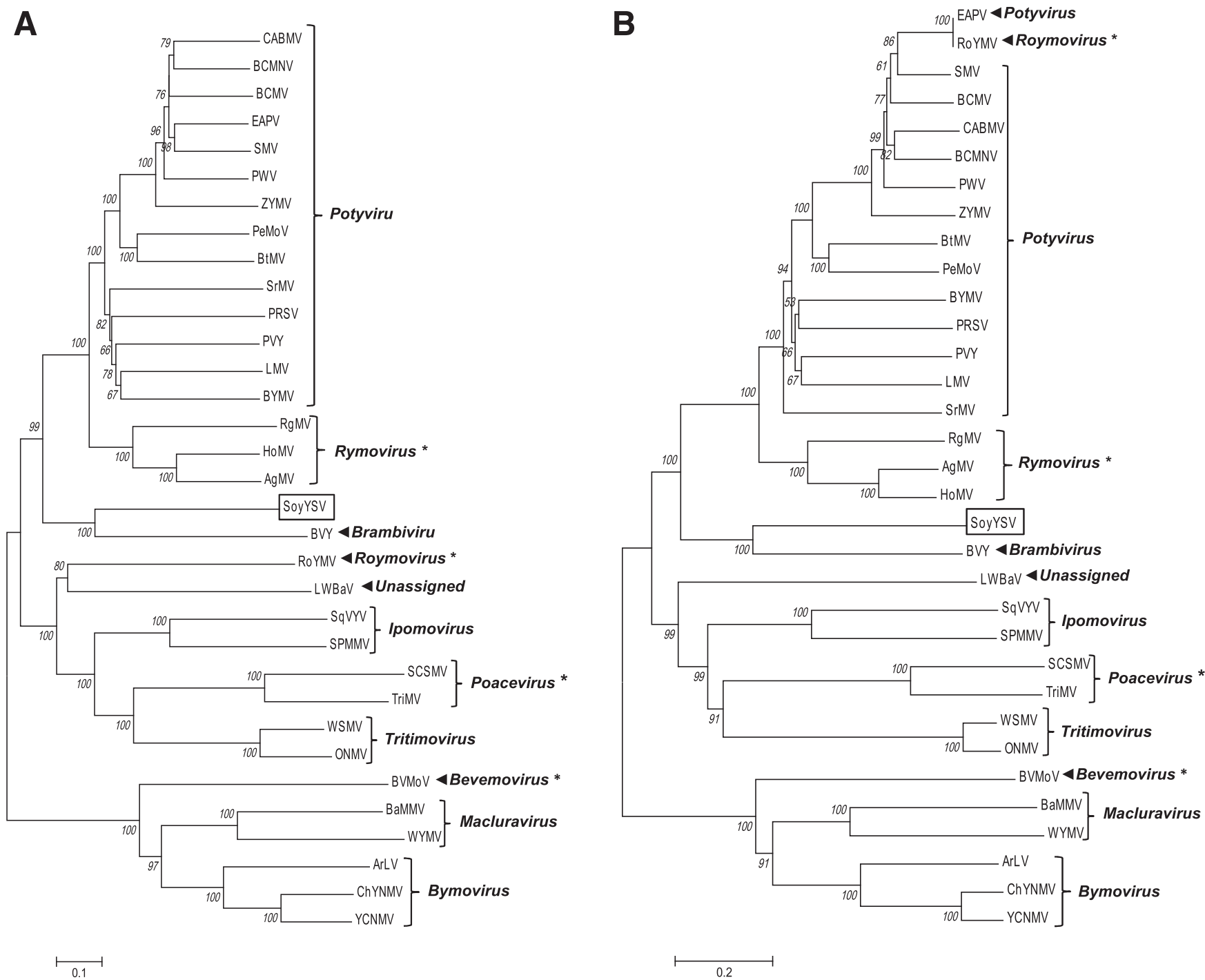

Fig. 3. Unrooted neighbor-joining phylogenetic trees reconstructed from the alignment of the full-length genomic nucleotide sequences of A, Soybean yellow shoot virus (SoyYSV) and B, polyprotein amino acid sequences. The trees were reconstructed with the MEGA7 program (Kumar et al. 2016) and percentages of bootstrap values (3,000 replicates) are indicated at the branch internodes. Asterisks indicate recently approved genera. Accession numbers and identification of the isolates from GenBank are as follows: virus isolate currently under study: SoyYSV (MH890547); Brambyvirus: Blackberry virus Y (BVY; NC_008558); Bymovirus: Barley mild mosaic virus (BaMMV; NC_003483) and Wheat yellow mosaic virus (WYMV; NC_002350); Ipomovirus: Squash vein yellowing virus (SqVYV; NC_010521) and Sweet potato mild mottle virus (SPMMV; NC_003797); Macluravirus: Artichoke latent virus isolate (ArLV; NC_026759), Chinese yam necrotic mosaic virus (ChYNMV; KX352243), and Yam chlorotic necrotic mosaic virus (YCNMV; MF072318); Poacevirus: Sugarcane streak mosaic virus (SCSMV*; NC_014037) and Triticum mosaic virus (TriMV*; NC_012799); Potyvirus: Bean common mosaic virus (BCMV; NC 003397), Bean common mosaic necrosis virus (BCMNV; NC_004047), Bean yellow mosaic virus (BYMV; NC_003492), Beet mosaic virus (BtMV; NC005304), Cowpea aphidborne mosaic virus (CABMV; NC004013), East Asian passiflora virus (EAPV; NC_007728), Lettuce mosaic virus (LMV; NC003605), Papaya ringspot virus (PRSV NC001785), Passion fruit woodiness virus (PWV; NC_014790), Peanut mottle virus (PeMoV; NC_002600), Potato virus Y (PVY; NC_001616), Soybean mosaic virus (SMV; NC_002634), Sorghum mosaic virus (SrMV; NC004035), and Zucchini yellow mosaic virus (ZYMV; KT598222); Rymovirus: Agropyron mosaic virus (AgMV; NC_005903), Hordeum mosaic virus (HoMV; NC_005904), and Ryegrass mosaic virus (RgMV; NC_001814); Tritimovirus: Oat necrotic mottle virus (ONMV; NC_005136) and Wheat streak mosaic virus (WSMV; NC_001886); Roymovirus: Rose yellow mosaic virus (RoYMV*; NC019031); Bevemovirus I: Bellflower veinal mottle virus (BVMoV*; NC_039002); and unassigned: Longan witches' broom-associated virus (LWBaV; NC_034835). 
In this study, the data obtained also lead to the conclusion that SoyYSV is a new Potyviridae species that does not fit into any existing genus of this family, and thus should currently be considered an unassigned member.

\section{Literature Cited}

Adams, M. J., Antoniw, J. F., and Beaudoin, F. 2005a. Overview and analysis of the polyprotein cleavage sites in the family Potyviridae. Mol. Plant Pathol. 6:471-487.

Adams, M. J., Antoniw, J. F., and Fauquet, C. M. 2005b. Molecular criteria for genus and species discrimination within the family Potyviridae. Arch. Virol. 150:459-479.

Almeida, A. M. R., Sakai, J., Hanada, K., Oliveira, T. G. O., Belintani, P., Kitajima, E. W., Souto, E. R., Novaes, T. G., and Nora, P. S. 2005. Biological and molecular characterization of an isolate of Tobacco streak virus obtained from soybeans in Brazil. Fitopatol. Bras. 30: 366-373.

Almeida, A. M. R., and Silveira, J. M. 1983. J.M. Efeito da idade de inoculação de plantas de soja com o vírus do mosaico comum da soja e da percentagem de plantas infectadas sobre o rendimento e algumas características econômicas. Fitopatol. Bras. 8:229-236.

Almeida, A. M. R., Yuki, V., Costa Val, W. M., Harada, A., Pola, J. N., and Turkiewsky, L. 1994. Epidemiological studies on soybean mosaic virus in Brazil. Fitopatol. Bras. 19:401-407.

Chung, B. Y., Miller, W. A., Atkins, J. F., and Firth, A. E. 2008. An overlapping essential gene in the Potyviridae. Proc. Natl. Acad. Sci. USA 105:5897-5902.

Coco, D., Calil, I. P., Brustolini, O. J. B., Santos, A. A., Inoue-Nagata, A. K., and Fontes, E. P. B. 2013. Soybean chlorotic spot virus, a novel begomovirus infecting soybean in Brazil. Arch. Virol. 158:457-462.

Companhia Nacional de Abastecimento. 2017. Grãos, Perspectivas para agropecuária. Vol. 5, Safra 2017-2018. https://www.conab.gov.br/OlalaCMS/ uploads/arquivos/17_09_06_09_30_08_perspectivas da_agropecuaria bx.pdf

Deslandes, J. A., Figueira, A. R., and Costa, A. S. 1984. Yellow top, a disease of soybean unlike mosaic also caused by a potyvirus. Summa Phytopathol. 10:25-26.

Dombrovsky, A., Huet, H., Chejanovsky, N., and Raccah, B. 2005. Aphid transmission of a potyvirus depends on suitability of the helper component and the $\mathrm{N}$ terminus of the coat protein. Arch. Virol. 150:287-298.

Dourado-Neto, D., Filho, R. V., Silva, A. A., Franco, R. B., and Correa, S. T. R. 2013. Interactions between soybean and weeds in a replacement series system, considering the effects of water stress. Planta Daninha 31:749-763.

Edwardson, J., Christie, R. G., and Ko, N. 1984. Potyvirus cylindrical inclusions subdivision IV. Phytopathol. 74:1111-1114.

Edwardson, J. R. 1966. Cylindrical inclusions in the cytoplasm of leaf cells infected with tobacco etch virus. Science 153:883-884.

Edwardson, J. R., and Christie, R. G. 1978. Use of virus-induced inclusions in classification and diagnosis. Annu. Rev. Phytopathol. 16:31-55.

Eskelin, K., Hafrén, A., Rantalainen, K. I., and Mäkinen, K. 2011. Potyviral VPg enhances viral RNA translation and inhibits reporter mRNA translation in planta. J. Virol. 85:9210-9221.

FAO. 2017. Faostat statistics database. http://www.fao.org/faostat/en/\#data/QC

Figueira, A. R., Reis, C. H., Alves, A. M. C., Kitajima and E. W. 1991. Studies with Soybean yellow shoot virus: New potyvirus detected in Brazil. Phytopathol. 81 (suppl.):693.

Flasinski, S., and Cassidy, B. G. 1998. Potyvirus aphid transmission requires helper component and homologous coat protein for maximal efficiency. Arch. Virol. 143:2159-2172.

Geraldino-Duarte, P. S., Galvino-Costa, S. B. F., and Figueira, A. R. 2012. Partial characterization of a new Potyvirus species infecting soybean plants in Brazil. Phytopathol. 102 (suppl.):S44.

Götz, R., Huth, W., Lesemann, D. E., and Maiss, E. 2002. Molecular and serological relationships of Spartina mottle virus (SpMV) strains from Spartina spec. and from Cynodon dactylon to other members of the Potyviridae. Arch. Virol. 147:379-391.

Goytia, E., Fernández-Calvino, L., Martínez-García, B., López-Abella, D., and López-Moya, J. J. 2006. Production of plum pox virus HC-Pro functionally active for aphid transmission in a transient-expression system. J. Gen. Virol. 87:3413-3423

Ha, C., Coombs, S., Revill, P. A., Harding, R. M., Vu, M., and Dale, J. L. 2008. Design and application of two novel degenerate primer pairs for the detection and complete genomic characterization of potyviruses. Arch. Virol. 153: 25-36.

Haas, B. J., Papanicolaou, A., Yassour, M., Grabherr, M., Blood, P. D., Bowden, J., Couger, M. B., Eccles, D., Li, B., Lieber, M., Macmanes, M. D., Ott, M., Orvis, J., Pochet, N., Strozzi, F., Weeks, N., Westerman, R., William, T., Dewey, C. N., Henschel, R., Leduc, R. D., Friedman, N., and Regev, A. 2013. De novo transcript sequence reconstruction from RNA-seq using the Trinity platform for reference generation and analysis. Nat. Protoc. 8: 1494-1512.

Hajimorad, M. R., Domier, L. L., Tolin, S. A., Whitham, S. A., and Saghai Maroof, M. A. 2018. Soybean mosaic virus: A successful potyvirus with a wide distribution but restricted natural host range. Mol. Plant Pathol. 19:1563-1579.
Hill, J. H., and Whitham, S. A. 2014. Control of virus diseases in soybeans. Adv. Virus Res. 90:355-390.

Hong, Y., and Hunt, A. G. 1996. RNA polymerase activity catalyzed by potyvirus encoded RNA-dependent RNA polymerase. Virol. 226:146-151.

Jamil, N., Rehman, A., Hamza, M., Hafeez, A., Ismail, H., Zubair, M., Mansoor, S., and Amin, I. 2017. First report of Tomato leaf curl New Delhi virus, a bipartite begomovirus, infecting soybean (Glycine max). Plant Dis. 101:845.

Kadaré, G., and Haenni, A. L. 1997. Virus-encoded RNA helicases. J. Virol. 71: 2583-2590.

Karnovsky, M. J. 1965. A formaldehyde-glutaraldehyde fixative of high osmolarity for use in electron microscopy. J. Cell Biol. 27:137-138.

Kumar, S., Stecher, G., and Tamura, K. 2016. MEGA7: Molecular Evolutionary Genetics Analysis version 7.0 for bigger datasets. Mol. Biol. Evol. 33: 1870-1874.

Lamprecht, R. L., Kasdorf, G. G. F., Stiller, M., Staples, S. M., Nel, L. H., and Pietersen, G. 2010. Soybean blotchy mosaic virus, a new Cytorhabdovirus found in South Africa. Plant Dis. 94:1348-1354.

Lane, L. C. 1992. A general method for detecting plant viruses. Pages 3-17 in: Plant Diseases of Viral, Viroid, Mycoplasma and Uncertain Origin. K. Maramorosch, ed. Oxford and IBH Publishing, New Delhi, India.

Marchler-Bauer, A., Bo, Y., Han, L., Christopher, J. H., Lanczycki, J., Lu, S. Chitsaz, F., Derbyshire, M. K., Geer, R. C., Gonzales, N. R., Gwadz, M. Hurwitz, D. I., Lu, F., Marchler, G. H., Song, J. S., Thanki, N., Wang, Z., Yamashita, R. A., Zhang, D., Zheng, C., Geer, L. E., and Bryant, S. H. 2017. CDD/SPARCLE: Functional classification of proteins via subfamily domain architectures. Nucleic Acids Res. 45:D200-D203.

Mollov, D., Lockhart, B., and Zlesak, D. 2013. Complete nucleotide sequence of rose yellow mosaic virus, a novel member of the family Potyviridae. Arch Virol. 158:1917-1923.

Moury, B., and Simon, V. 2011. dN/dS-based methods detect positive selection linked to trade-offs between different fitness traits in the coat protein of Potato virus Y. Mol. Biol. Evol. 28:2707-2717.

NCBI Resource Coordinators. 2018. Database resources of the National Center for Biotechnology Information. Nucleic Acids Res. 46:D8-D13.

Nei, M., and Gojobori, T. 1986. Simple methods for estimating the numbers of synonymous and nonsynonymous nucleotide substitutions. Mol. Biol. Evol. 3:418-426

Plisson, C., Drucker, M., Blanc, S., German-Retana, S., Le Gall, G., Daniel Thomas, D., and Bron, P. 2003. Structural characterization of HC-Pro, a plant virus multifunctional protein. J. Biol. Chem. 278:23753-23761.

Revers, F., and García, J. A. 2015. Molecular biology of potyviruses. Adv. Virus Res. 92:101-199.

Seo, J. K., Kang, S. H., Seo, B. Y., Jung, J. K., and Kim, K. H. 2010. Mutational analysis of interaction between coat protein and helper component-proteinase of Soybean mosaic virus involved in aphid transmission. Mol. Plant Pathol. 11: 265-276.

Seo, J. K., Kim, M. K., Kwak, H. R., Kim, J. S., and Choi, H. S. 2017a. Complete genome sequence of longan witches' broom-associated virus, a novel member of the family Potyviridae [erratum published in Arch. Virol. 2017;162:2891]. Arch. Virol. 162:2885-2889.

Seo, J. K., Kwak, H. R., Kim, M. K., Kim, J. S., and Choi, H. S. 2017b. The complete genome sequence of a novel virus, bellflower veinal mottle virus, suggests the existence of a new genus within the family Potyviridae. Arch. Virol. 162:2457-2461.

Siaw, F. E., Shahabuddin, M., Ballard, S., Shaw, J. G., and Rhoads, R. E. 1985 Identification of a protein covalently linked to the $5^{\prime}$ terminus of tobacco vein mottling virus RNA. Virol. 142:134-143.

Silva, M. F., Almeida, A. M. R., and Arias, C. A. A. 2003. Evaluation of losses caused by two strains of Soybean mosaic virus in two soybean cultivars [Avaliação de danos causados por duas estirpes do Soybean mosaic virus em duas cultivares de soja]. Fitopatol. Bras. 28:597-601.

Sorel, M., Garcia, J. A., and German-Retana, S. 2014. The Potyviridae cylindrical inclusion helicase: A key multipartner and multifunctional protein. Mol. Plant Microbe Interact. 27:215-226.

Stenger, D. C., Hein, G. L., and French, R. 2006. Nested deletion analysis of Wheat streak mosaic virus HC-Pro: Mapping of domains affecting polyprotein processing and eriophyid mite transmission. Virol. 350:465-474.

Tatineni, S., Ziems, A. D., Wegulo, S. N., and French, R. 2009. Triticum mosaic virus: A distinct member of the family Potyviridae with an unusually long leader sequence. Phytopatol. 99:943-950.

Verchot, J., Koonin, E. V., and Carrington, J. C. 1991. The $35 \mathrm{kDa}$ protein from the $\mathrm{N}$-terminus of the potyviral polyprotein functions as the third viral-encoded proteinase. Virol. 185:527-535.

Voloudakis, A. E., Malpica, C. A., Aleman-Verdaguer, M.-E., Stark, D. M., Fauquet, C. M., and Beachy, R. N. 2004. Structural characterization of Tobacco etch virus coat protein mutants. Arch. Virol. 149:699-712.

Whitfield, A. E., Falk, B. W., and Rotenberg, D. 2015. Insect vector-mediated transmission of plant viruses. Virol. 479-480:278-289.

Wylie, S. J., Adams, M., Chalam, C., Kreuze, J., López-Moya, J. J., Ohshima K., Praveen, S., Rabenstein, F., Stenger, D., Wang, A., and Zerbini, F. M ICTV Report Consortium. 2017. ICTV Virus Taxonomy Profile: Potyviridae [erratum published in J. Gen. Virol. 2017;98:2893]. J. Gen. Virol. 98:352-354. 
Xu, D. L., Zhou, G. H., Xie, Y. J., Mock, R., and Li, R. 2010. Complete nucleotide sequence and taxonomy of Sugarcane streak mosaic virus, member of a novel genus in the family Potyviridae. Virus Genes 40:432-439.

Yasmin, T., Nelson, B. D., Hobbs, H. A., McCoppin, N. K., Lambert, K. N., and Domier, L. L. 2017. Molecular characterization of a new soybean-infecting member of the genus Nepovirus identified by high-throughput sequencing. Arch. Virol. 162:1089-1092.

Zanardo, L. G., Silva, F. N., Lima, A. T., Milanesi, D. F., Castilho-Urquiza, G. P., Almeida, A. M., Zerbini, F. M., and Carvalho, C. M. 2014. Molecular variability of cowpea mild mottle virus infecting soybean in Brazil. Arch. Virol. 159:727-737. 